\title{
The Transformation of Work in Digitized Public Sector Organizations
}

Plesner, Ursula; Justesen, Lise; Glerup, Cecilie

\author{
Document Version \\ Accepted author manuscript \\ Published in: \\ Journal of Organizational Change Management
}

DOI:

10.1108/JOCM-06-2017-0257

Publication date:

2018

License

Unspecified

Citation for published version (APA):

Plesner, U., Justesen, L., \& Glerup, C. (2018). The Transformation of Work in Digitized Public Sector Organizations. Journal of Organizational Change Management, 31(5), 1176-1190.

https://doi.org/10.1108/JOCM-06-2017-0257

Link to publication in CBS Research Portal

\section{General rights}

Copyright and moral rights for the publications made accessible in the public portal are retained by the authors and/or other copyright owners and it is a condition of accessing publications that users recognise and abide by the legal requirements associated with these rights.

\section{Take down policy}

If you believe that this document breaches copyright please contact us (research.lib@cbs.dk) providing details, and we will remove access to the work immediately and investigate your claim.

Download date: 26. Apr. 2023
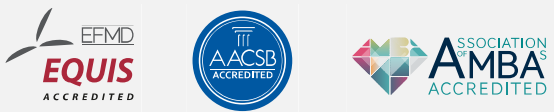


\title{
The Transformation of Work in Digitized Public Sector Organizations
}

\author{
Ursula Plesner, Lise Justesen, and Cecilie Glerup
}

Journal article (Accepted manuscript*)

\section{Please cite this article as:}

Plesner, U., Justesen, L., \& Glerup, С. (2018). The Transformation of Work in Digitized Public Sector Organizations. Journal of Organizational Change Management, 315), 1176-1190. 00l: 10.1108/J0CM-06-20170257

\section{DOI: 10.1108/JOCM-06-2017-0257}

This article is [0 Emerald Group Publishing and permission has been granted for this version to appear here: https://research.cbs.dk/en/publications/the-transformation-of-work-in-digitized-public-sector-organizatio-2.

Emerald does not grant permission for this article to be further copied/distributed or hosted elsewhere without the express permission from Emerald Group Publishing Limited.

* This version of the article has been accepted for publication and undergone full peer review but has not been through the copyediting, typesetting, pagination and proofreading process, which may lead to differences between this version and the publisher's final version AKA Version of Record. 


\section{Introduction}

Digitization of service and work processes is profoundly changing public sector organizations across the Western world. From government administrations' electronic handling of vast amounts of paperwork and digital communication with citizens to the introduction of robots in home care and smart boards in schools, digitization has become an essential component of most government reforms. The OECD continuously monitors its member states' progress in this regard, as digitization is viewed as a solution to 'big issues', such as high public expenditures, ineffectiveness, user involvement, and the need for transparency in public administration (OECD, 2009). Some scholars in the field of public administration refer to digitization of the public sector as e-government (Bekkers and Homburg, 2005) or digital-era governance (Margetts, 2009) and suggest that this is a new and highly influential trend in the public sector, comparable in scope with - and partly replacing - New Public Management (Dunleavy et al., 2006).

The aim of this article is to examine what we can learn from organization studies of digital technologies and changes in public organizations and to develop a research agenda that allows us to produce systematic knowledge about how work practices in the public sector change with digitization. By systematic we mean crossorganizational research highlighting themes, which cut across different sectors and contribute to transforming the public sector at large. While the changes caused by political reforms on public service have been on both the public and the academic agenda (du Gay, 2009), the reforms' recurrent focus on the digitization of work has curiously not gained much scholarly attention in organization studies. This is remarkable since the relationship between work, technology and change has been a central object of study in this field since Taylor's (1911) principle of scientific management, followed by classic works showing that different types of technology have different implications for effective organizational structures (Galbraith, 1977; Perrow, 1967; Woodward, 1958). Technology is often understood as 'devices' to be implemented in organizations to enhance production or work processes. By contrast, we draw on an understanding of technology as an unstable, unpredictable phenomenon. It is shaped by social forces (in our case, e.g. the digitization agenda), 
technical design (e.g., specific online platforms), and local users (e.g., public sector managers and employees.

The pervasiveness of digital technologies in contemporary organizations has led organization scholars to revitalize the concept of technology in organization studies (e.g. Kallinikos, 2006; Orlikowski, 2007). Most work in the area draws on individual case studies of organizations in the private sector, and, with some notable exceptions (Pors, 2015; Introna et. al., 2009; Harris, 2006; 2008; Yeo and Marquardt, 2015; Hossan et al., 2013), the digitization of the public sector remains an underexplored area within organization studies as well as in the subfield of organizational change management studies. The studies that do focus on change caused by digitization in public sector organizations tend to focus on the implementation of a particular technology in a particular public organization, and do not theorize the public sector as a specific change context (e.g. Hung et al., 2009; Hussenot, 2008). This is a paradoxical shortcoming in organization studies because much of the literature insists that technologies, including digital technologies, can only be understood by taking the specific context into consideration.

The lack of attention to digitization in public organizations corresponds to an overall fading interest in public sector organizations in organization studies (Arellano-Gault et al., 2013). A similar tendency to ignore public sector organizations can be observed in the change management literature. Pick et al. (2015, p. n/a) state that "the change management literature has tended to focus on the private sector with little attention being paid to the way public sector workers experience and respond to change".

In this article, we argue that the public sector constitutes a specific context for digitization and that the specificities of public sector organizations should be further examined in order to contextualize digitalization and its implications for work. We assume that digitization is a multifaceted phenomenon (Buffat, 2015; Jæger and Löfgren, 2010). It reconfigures public sector organizations in fundamental, although uneven, ways and changes the daily work-life of public servants.

The term digitization commonly covers the introduction of a broad range of technologies, from tracking devices in waste management over digital self-service to new systems of data production and analysis. But digitization is more than the implementation and use of particular technologies. In their definition of digitization, 
Ejersbo and Greve (2017, p. 269) emphasize a holistic ambition behind digitization: "Digitization focuses on digital changes and the opportunity to 'completely embrace' digital solutions in contact with users/citizens, i.e. digitizing interactions with citizens and business". In that way, digitization is not only a question of technologies but also encompasses a set of managerial and governmental ideas and ideals centered on the aim of improving the public sector (Dunleavy et al., 2006). Similar to other public sector reforms, digitization can be understood in terms of a "comprehensive political intervention" (Bejerot and Hasselbladh, 2013). It involves a fundamental rethinking and reshaping of the entire public sector and its organizations. In this way, digitization can be seen as a broad set of practices characterized by normative, programmatic as well as technological, operational elements (Power, 1999). In line with Power, we understand the programmatic elements as "the ideas and concepts that shape the mission of the practice and which, crucially, attach the practice to the broader policy objectives which exist in the political sphere" (ibid., p. 6). The programmatic elements are loosely coupled with the technological elements, as they are visible in the "concrete tasks and routines which make up the world of practitioners" (ibid.). This implies that digitization takes on a specific form in the public sector because it becomes entangled with programmatic ideals related to broader modernization agendas. At the same time, the operational elements - the interactions between the technology and its local context—result in changes of daily work practices.

The remainder of the article is structured in the following way. First, we argue that digitization is a major change factor in contemporary organizations, and we point to some grand utopian and dystopian narratives about the phenomenon. We then turn to different research traditions, which go beyond the grand narratives and either study implementation of specific digital technologies in organizations, or analyze digitization as part of public reform programs. We propose that organization studies' focus on work practices offer a useful entry point to understanding how work in the public sector is transformed by digitization. Then we unfold the argument that public sector organizations operate under specific conditions and that this issue is underexplored in organization studies. We suggest that those specific conditions can be captured by a focus on bureaucratic formal structures, accountability and professions. Next, we conduct an analysis of organization studies literature on digital technologies and organization in the public sector. We highlight a number of case- 
based studies, which illustrate how digital technologies lead to changes in public sector organizations at the everyday level of the organization. Even if they do not explicitly address digitization as a broader phenomenon or the public sector as a specific context, a close reading of these studies in light of the themes of formal bureaucratic structures, accountability and professions shows that extant research does indicate that digital technologies affect such key organizational dimensions. On this basis, we argue for more systematic studies to understand how digitization transforms work in public sector organizations. We then propose an agenda for further research into the relationship between digitization and formal bureaucratic structures, accountability, and professionals. This is followed by a reflection on managerial implications and a brief conclusion.

\section{Digitization as a major change factor}

In the public debate as well as in popularized research, digitization is often described in grand future-oriented narratives. Some celebrate it as a means to finally solve efficiency and quality problems. Others warn us about "the rise of the robots" (Ford, 2016) or the massive unemployment that will follow in the wake of Artificial Intelligence (Susskind and Susskind, 2015). Both utopian and dystopian accounts revolve around the fashionable term 'disruption', but tell us little about how digitization changes everyday work practices at the concrete level. Whereas the dystopian accounts mostly focus on job redundancies, scattered evidence suggests that new tasks, structures, roles, relations and responsibilities follow from digitization. The sweeping grand narratives tend to ignore these multiple consequences of digitization (Wajcman, 2017).

Furthermore, the public sector is not treated as a specific context by these accounts. This is notable since digitization is currently a major change factor in the public sector and substantial investments in digital technologies are made in this sector. Digitization has become an integrated element of e-government, which some scholars consider a new movement in public administration (Yeo \& Marquardt, 2015). From many sides, public sector organizations are called upon to develop more ambitious digitization strategies by 'digitizing in depth' or by embracing fourth generation information technology. For example, public organizations are urged to benefit from the Internet of Things (Watts, 2016) for instance in the design of Smart Cities, to 
profit from Big Data analyses (Maciejewski, 2017) to support decision-making, and to ensure interoperability (Landsbergen and Wolken, 2001) so that disparate public information systems begin to 'speak to one another'.

A prominent strand of research that does focus specificically on public sector digitization has been produced by public administration scholars (Pors, 2015). With some notable exceptions (e.g. Introna et al., 2009; Buffat, 2015), they tend to approach digitization from a macro perspective as an innovative strategy for organizing public administration and service delivery (Lips, 2012) and as a supplement to or replacement for NPM (Dunleavy et al., 2006). The concepts of 'Egovernment' (Bekkers and Homburg, 2005) and 'Digital-Era Governance' (Dunleavy et al., 2006) have been coined by scholars within this field of research. The public administration literature offers evidence of the scope and the nature of the digitization agenda, but it says relatively little about the transformation of work and organization in the digitized public sector.

In clear contrast to the grand narratives mentioned above, but also different from the macro perspective prevalent in public administration theory, we find several empirically grounded case studies of IT implementation in the field of Information Systems (IS) research. The focus here is often on precisely the implementation and adaptation of specific digital technologies in organizations. Many of these studies focus on implementation success or failure, and it is a recurrent finding that user perception makes an important difference in many implementation projects (e.g. Davis and Hufnagel, 2007). Information Systems research challenges the more speculative accounts of the 'digital age' by bringing attention to the fact that technological development is not determining organizational issues. They show us that empirically grounded studies are important if we are to understand the specific consequence of digital technologies because they take us beyond the policy level and the programmatic aspirations and illustrate the multiple ways technologies can enter organizations, altering organizations and being altered by them. But if digitization is seen as a question of implementation of a specific digital technology, we may overlook the programmatic aspects of digitization as well as the specific form this attains in a public sector context. Numerous IS case studies examine public sector organizations, particularly the health care sector, but with a few notable exceptions (e.g. Kraemer and King, 1986), little attention has been paid to this question. 
Organization studies have to a large extent followed the approach in IS and tend also to conduct case studies of particular digtial technologies in organizations. It is clear that organization studies and IS have overlapping interests, and many of the studies discussed below are positioned in both traditions and, for instance, published in the interdisciplinary journal Information and Organization (e.g. Boudreau et al., 2014; Sørensen and Pica, 2005; Bloomfield and MacLean, 2003). But organization theory can provide a theoretical framework and analytical vocabularies that make it possible to address questions about digitization both as a broder phenonomon than implementation of digital technologies, as defined above, and as an organizational change factor at an everyday level. As argued by Barley and Kunda (2001, p. 76) this is because "[a]11 theories of organizing are at least implicitly linked to some image of the concrete activities that they purport to describe and explain. In most instances, these activities are what people call work". Studying various aspects of work, we are able to see

"that digital technologies are used in a variety of ways and have a variety of effects on the way firms organize. They can automate or informate work (Zuboff 1988), they can create or eliminate jobs (Barley 1988), they can deskill, enskill, or reskill work (Spenner 1995, Diprete 1988), and more often than we think, they may occasion no change at all (Gallie 1994)" (Barley and Kunda 2001, p. 79)

Although Barley and Kunda refer to digtial technologies rather than digitization as defined above, their point is valid to our purpose because they emphasize that work is a key concept in organization studies, also in relation to technology. This is in line with du Gay and Vikkelsø (2017) who argue that formal organizing and its connection to 'work itself' originially constituted the core of organization theory as a disciplin. In their view, this connection between concrete work and formal organizing is both the rasion d'etre and the distinguishing feature of organizational theory. Following these lines of reasoning, it is relevant to turn to organization studies if we want to enhance our understanding of how work is transformed in digitized public sector organizations. Organizations studies provide us with a rich vocabulary that makes it possible to study the interplay between technologies, work and organization in a specific context - the public sector - that must also be taken into account. 


\section{Public sector organizations as a specific context}

Digitization is altering work practices in many types of organizations across the public/private sector divide. Yet, the ways in which work is organized and performed in public sector organizations differ significantly from other types of organizations in certain respects. If we assume that digitization is a multifaceted phenomenon that is shaped by its organizational context this calls for examinations of the public sector as a unique context for digitization. First, digitization in the public sector is different from private sector digitization because, as discussed above, it becomes part of a "holistic" (Ejersbo and Greve, 2017), movement-like way of thinking public sector reforms and change, based on strong programmatic ideals. It is not just a question of implementing new digital technologies, but implies political ideas, ambitions and interventions aimed at fundamentally rethinking and reshaping the organizations. Secondly, public sector organizations operate under different conditions than private sector organizations. In Bejerot and Hasselbladh's (2013, p. 1358) terms, public sector organizations are "“wired' differently" compared to private sector organizations because the former are "largely run according to laws and political decisions" (ibid.) and, in addition, often subjected to specific accounting and accountability requirements. In that way, public sector organizations have considerably less discretion to set their own criteria of success and to define their own end goals (Arellano-Gault et al., 2013, p. 155). They operate under different "regime values" that, according to du Gay (2000, p. 7), are "mainly [...] imposed by the political environment in which public governmental work is conducted".

To further explore how digitization is different in the public sector, we focus analytically on three organizational aspects that, we argue, take specific shapes in the public sector: formal bureaucratic structures, accountability and professionals. The three aspects can be treated as separate analytical categories, but should not be seen as internally exclusive. Rather they overlap in practice and in empirical studies, just like they can easily become entangled with other analytical categories, as we will see in our discussion of organizational studies of digitization of public sector organizations below. Although the three aspects can be constructed as analytically distinct, it can be argued that they are connected by a specific ethos of office, which is historically tied to the public sector and its professionals (Weber, 1978; du Gay, 2000). 
While formal structures are a basic feature of most organizations, they have a particular significance in the public sector because the strict procedural handling of affairs is a way to secure equality and transparency in public administration (du Gay, 2000). In that way, formal structures are related to accountability, which also takes different forms in the public than in the private sector because the public sector handles communally shared resources and is accountable to politically set goals as part of the democratic process. According to Lipsky (2010, p. 160), “[a]ccountability is the link between bureaucracy and democracy". This implies different conditions for professionals in the public sector because professionals are dependent on political decisions and held accountable for these. The programmatic dimension of digitization of the public sector makes it relevant to investigate how these three dimensions of public sector organizations are changing due to a range of effects arising from the powerful digitization agenda.

While a conceptual framework encompassing these three aspects is not exhaustive, it does lead our attention to a wide range of important work practices shaped by the particularity of public sector organizations. For that reason, we have chosen to focus on these three categories as a lens through which we analyse and discuss relevant literature in organization studies. As mentioned previously, other research traditions have studied digitization of the public sector from more technical or administrative perspectives, but organization studies have traditionally empirically investigated the work practices that are shaped by and shaping formal bureaucratic structures, accountabilities and professionals. A distinctly organizational view on these aspects thus allows for a particular view on work practices and it makes it possible to pose a particular set of questions as exemplified by the following table.

\begin{tabular}{|c|c|c|c|}
\hline THEME & Structures & Accountabilities & Professionals \\
\hline $\begin{array}{l}\text { EMPIRICAL } \\
\text { FOCUS ON } \\
\text { SITUATED } \\
\text { WORK } \\
\text { PRACTICES }\end{array}$ & $\begin{array}{l}\text { How managers } \\
\text { redesign } \\
\text { structures, create } \\
\text { new tasks, new } \\
\text { occupational } \\
\text { categories, new } \\
\text { groups, new }\end{array}$ & $\begin{array}{l}\text { How managers and } \\
\text { employees handle } \\
\text { new demands to } \\
\text { registration, } \\
\text { information } \\
\text { management, } \\
\text { delegation of work to }\end{array}$ & $\begin{array}{l}\text { How employees } \\
\text { redefine } \\
\text { professional } \\
\text { relations and } \\
\text { identities in } \\
\text { interplay with new } \\
\text { tasks and positions }\end{array}$ \\
\hline
\end{tabular}




\begin{tabular}{|l|l|l|l|}
\hline & $\begin{array}{l}\text { routines and how } \\
\text { employees respond } \\
\text { to the restructuring }\end{array}$ & $\begin{array}{l}\text { technology, } \\
\text { delegation of } \\
\text { responsibility }\end{array}$ & in the organization \\
\hline
\end{tabular}

These questions provide a focus on important dimensions of work that can be examined by using the vocabulary of organization theory. The following sections discuss how research in organization studies has provided often-implicit insights about digitization in relation to formal bureaucratic structures, accountability and professionals. We introduce each of the three sections by fleshing out why and how the theme is important for our understanding of the transformation of work in the digitized public organization.

\section{Digitization and formal bureaucratic structures} Organization theory has traditionally revolved around formal aspects of organization and viewed organizations as units purposively constructed to attain formulated goals with the help of explicit authority structures and roles (du Gay and Vikkels $\varnothing$, 2017). Scholars in the field have been concerned with how coordination, communication and division of work are ensured through the design of formal organizational structures. Structuring or restructuring an organization is a practical discipline, which is often an ongoing managerial concern. (ibid.). As illustrated in the tabel above, organization studies alert us to the activities of structuring and restructuring organizations to pursue their core tasks.

The formal bureaucratic structures in the public sector are interesting objects of study because they are constructed to ensure not only efficiency, but also effectiveness and public legitimacy. In organization studies, there has not been sustained interest in how increased horizontal collaboration and data sharing afforded by digitization affect the formal bureaucratic structures of public sector organizations. But a few articles touch upon the relationship between digitization and formal bureaucratic structures. Some of the articles show that even if bureaucracies change due to digitization, their basic structures are still present in the daily organization of work in the public sector. For instance, in his study of the British Library, Harris (2006; 2008) found that despite increased marketization, several features of the 'classic' bureaucratic organization 
remain untouched - for instance, elements of hierarchical management. His studies point to the emergence of new hybrid organizational forms as a result of IT innovation. Boisot (2006) arrived at a similar conclusion about stability versus change in structures. He proposes that public bureaucracies have proven to be very strong institutions, especially with regard to the diffusion of knowledge in the public sector. The same is demonstrated by Sørensen and Pica (2005) in their study of how the police establish rules for mobile phone use. In that process, they transfer their procedural work structures into a digital work reality and formal bureaucratic structures are re-constructed from the bottom up. These studies indicate that formal bureaucratic structures prevail in digitized public organizations despite proposals that digitization might be connected to "the end of bureaucracy" (Harris 2006; 2008).

Pointing in another direction, Yeo and Marquardt (2015) argue that digitization blurs the boundaries between organizations or even breaks down strict organizational boundaries as we know them. In their case study of a public organization in Malaysia, they show that new digital technologies introduced new flexible communication channels that led to a shift in the organization "from defined, inflexible, and hierarchical structures to more spontaneous and fluid role structures making coordination easier" (p. 19) and they quote one of their respondents for saying that this change "literally chipped off the pyramid structure" in the organization (ibid.). This meant that gaps between employees and decision-makers were reduced and new horizontal relations replaced the old vertical structures. Other scholars of change management have pointed out that implementation of 'e-service' is partly challenged by the need to simultaneously change structures and boundaries within the public sector (Hossan et al., 2013).

The studies discussed above point in different directions. While all contain useful observations, they can also be seen as supporting our claim that we have a limited understanding of the effects of digitization on public bureaucratic structures. From a democratic perspective, changes in formal structures might raise issues regarding transparency, legitimacy, and accountability. We turn to these issues in the following section. 


\section{Digitization and new accountabilities}

The notions of bureaucracy, bureaucratic ethos and accountability are closely related (du Gay, 2000) and it seems safe to assume that digitization not only affects formal bureaucratic structures, but also leads to new forms of accountability in public sector organizations. Public organizations are held accountable for their work with digitization and subjected to new forms of control that affect the organization in different ways. Power (1999) points out that today's "audit society" is characterized by an increasing desire to check performance and ensure value for money in the public sector. This implies that more control mechanisms are installed at the organizational level, aimed at making performance visible and measurable and, thereby, auditable. The organization is held accountable for its performance in the dual sense of the term - responsible for organizational performance and being able to formally account for that performance. Digitization is part of this ambition both because it creates new digital audit trails and makes work visible in new ways and because its effects need to be measured and assessed when it is part of major reforms. This calls for investigations into how the digitization agenda changes control and accountability in public organizations. It is relevant to ask how accountabilities are redistributed if fundamental organizational procedures are digitized and if professional judgment is partly replaced with standardized, digitized solutions.

Yet, only few articles on digitization in public sector organization mention accountability and even fewer take this aspect into consideration in their analyses. Some studies mention accountability issues in the healthcare sector. For instance, Bloomfield and McLean (2003) examined how the introduction of a new information system in the British healthcare sector affected the organization of mental health services. Their case study of a psychiatric department at a large hospital showed that the information system resulted in an increased focus on documentation. It was no longer the case that good practice simply had to be followed. Instead, the hospital had to meticulously document that it was acting in accordance with the standards of the system and patients were continuously called upon to self-report. The study shows that when an organization becomes physically dispersed (because most patients are no longer in the hospital), it invents new ways of making the absent present. The information system becomes important in this regard because it makes both patients 
and health professionals "visible and accountable" in certain ways (ibid., p. 68). This is seen as "opening up to surveillance, to inspection and audit" (ibid., p. 69).

In a study of electronic patient record implementation in an English hospital, Petrakaki et al. (2016) argue similarly that the new system enhanced visibility in the organization. Previously invisible work practices and decision-making became visible because new kinds of information had to be stored electronically in the new system. The system established a historical log, which made it possible for both peers and external parties to control healthcare professionals in new ways. The increased demands for documentation led to new kinds of accountability because different groups of healthcare professionals were held accountable for compliance with clinical standards and operating procedures, and compliance could be checked continuously (ibid, p. 219). This new horizontal visibility "afforded conformity to due clinical process from fear of making errors or omissions visible to peers" (ibid.).

The case study by Yeo and Marquardt (2015) mentioned in the previous section shows how data leak and misuse of information followed when the case organization increased data storage and data accessiblity. The authors interpret these examples as "a typical scenario of how organizational leaders, in their eagerness to solve a particular IT problem, lost sight of their accountability of data and critical information" (p. 520).

None of these studies are mainly focused on accountability and they do not discuss theoretically how this particular aspect changes when the healthcare sector is digitized. Nevertheless, they show empirically that accountability relations change in the digitized empirical contexts described. The vast increase in the call for documentation of work practices and decisions seems to externalize professional accountability. This is not only a question of adhering to professional norms, but also of documenting that adherence in a way that is consistent with the system. The establishment of an audit trail becomes important. As shown across the studies, this implies that professionals spend an increasing amount of time on documentation and record keeping. Notably, although all authors draw on case studies from the public sector, they do not discuss how this specific context affects their findings. For example, although they do not unfold it in their brief discussion of accountability, Yeo and Marquardt's (2015) study point to the issue of sensitive data protection. 
While this is of course also relevant to private sector organizations, it has a particular relevance in the public sector because the legitimacy of the public administration is highly dependent on its ability to store and treat sensitive data in accordance with strict legislation and high ethical standards.

If we assume that public sector accountability is fundamentally different from private sector accountability, examinations of how digitization in the public sector specifically affects public sector accountability seem important. As already indicated above, the issue of changing accountabilities also raises the question of how public professionals react to digitization, as they are made accountable in new ways in the new organizational contexts. According to Strathern (2000, p. 1), accountability is how "the moral and the financial meet" in organizations today. It is not only about formal procedures, but also has a strong normative aspect related to the specific public sector values and virtues. Both aspects of accountability could play an important part in reconstructing the public professional - the issue we want to discuss in the next section.

\section{Digitization and the reconstruction of the public professional}

A broad stream in organization studies has produced knowledge about dynamics between people in organizations by focusing on the development and maintenance of professions as well as the interactions between professionals (Abbott, 1988). These interactions can be seen as central to the execution of work, and organization studies alert us to the hierarchies, struggles and collaboration between professionals. As the previous sections suggest, the digitization of the public sector changes many traditional tasks, demands and relations. Some tasks have simply disappeared, while the character of others has changed. For instance, modern casework sometimes amounts to helping citizens help themselves online, and administrative planning has become a matter of correcting mistakes made in digital planning tools. This change in the character of tasks might be accompanied by a change in professional identity. However, what happens to professional identities in relation to the digitization phenomenon remains largely unexplored, as does the effects on employees' sense of meaning and work satisfaction. Public servants might, for example, experience a sort of de-professionalization (Toren, 1975) when structures and accountability practices 
change, or they may become detached from classical bureaucratic ethics and more attached to professional ideals in line with engaged project managers or business leaders (du Gay, 2009; Pors, 2015). It is therefore relevant to investigate reconfigurations of professional identities and relations among employees in organizations heavily affected by digitization.

Organization studies do offer empirical accounts of changes in professional relations and identities as a consequence of digitization, but, again, these studies do not explicitly discuss their results in the light of the particularity of a public sector organization. Still, they do offer observations that are highly relevant as a basis for investigating and theorizing how public professionals are reconstructed in digitized public organizations.

Some studies analyze how relations between public professionals and citizens have been altered by digitization, and discuss the implications for professional practice. For example, in her study of a municipality citizen service, Pors (2015) shows how the mode of professionalism changed from being one of service to being one of support after digital self-service was introduced. Much of the work of accessing or entering information was handed over to citizens and the role of the employee became to guide or facilitate this. In such situations, the employee has to deal with the physical move from face-to-face encounters from behind the desk to 'shoulder to shoulder' encounters in front of the same computer. The citizen has access to systems and information, the relation becomes more equal, and there is less need for authoritative case-handling or specialized knowledge, and more need for social skills (ibid.).

The study of mental health services mentioned in the previous section (Bloomfield and MacLean, 2003) showed that the changes brought about by the "virtualization" of mental care practices also have implications for professional identities and practices. When patients are no longer inside a physical building, health professionals need to keep track of them through an increasing amount of documentation in standardized formats. In other words, professionals become managers of information (ibid., p. 66). A similar situation has arisen for librarians in book-free libraries (Boudreau et al., 2014). When a library becomes virtual, it becomes more difficult for librarians to uphold the relation they had with citizens when they were 'custodians of the books'. When books were physical, librarians were also visible as someone to consult. 
Boudreau et al. (2014) studied how librarians felt a need to redefine their tasks and professional identities when all material was digitized. Librarians found themselves operating in an environment in which information search only happened on computers and they were no longer recognized as relevant professionals to consult. They therefore began to advertise their presence and the possibility of asking for help, but this resulted in a frustrating number of directional or practical questions. As the librarians were not interested in becoming clerical workers, they chose to approach citizens online and expose their professionalism there. In this way, the study shows how a change in tasks entails ongoing efforts to redefine professionalism.

In addition to the literature investigating changing relations between public professionals and citizens, several studies are concerned with how digitization transforms professional roles and relations between various types of professionals as a result of new tasks and routines within public organizations. For instance, the study of electronic patient records discussed earlier (Petrakaki et al., 2016) also showed that when electronic requests and clinical information can travel across clinical boundaries, both professional work and power relations are restructured. The conduct of healthcare professionals becomes more standardized, professional autonomy is curtailed, and the introduction of new tasks means that new roles are established. For instance, nurses experience an enlargement of their professional role because they become responsible for embedding technology in their work, monitoring data, and ensuring proper patient care. At the same time, the established hierarchical relation between doctors and nurses is reinforced because doctors refuse to engage with the technology, which they view as a non-clinical practice. Interestingly, nurses seem to maintain and enhance their professional identity by extending it to "patient data custodians and curators" (ibid., p. 220).

Similarly, a study of the introduction of robotics in a hospital pharmacy concluded that some professional groups can acquire more authority and prestige if they are able to interact with digital technology in smart ways (Barrett et al., 2012). This study exemplifies how accounts of the introduction of digital technologies are often stories of struggles among different professionals, some of whom view a new technology as promising while others view it as disturbing (Constaninedes and Barrett, 2006; Segrest et al., 1998). A study of the introduction of an IT-system in the military showed that the implementation only reinforced a very hierarchical organization and, 
on top of this, it led to a sense of deskilling and a mounting dissatisfaction among employees (Tolsby, 2000).

A final example from the literature on digitization of public organizations refers to changed practices and professional roles, but without mentioning a conflict dimension (Lanzara, 2010). The study covers courtroom practices where video technology and an online presence threw judges' well-established professional practices into question. The introduction of digital technologies into the courtroom created a new range of observable facts, which judges needed to deal with in new ways. The judges' struggles were not with other professionals, but with maintaining their professional status in an altered organizational setting.

Across organization studies that address altered professional relations and identities as a consequence of digitization, a common interest revolves around what we might call the 'virtualization' of a range of practices. Conflict and struggles are often identified as outcomes of collaborating on and around digital platforms. Aspects that seem central to studies of public sector organizations are the move of professionals towards an information management role and the effort needed to make sense of new professional roles, relations and identities. However, as pointed out earlier, in the literature, this emphasis on redefining professions is not linked to the particularities of the empirical setting - the public sector organization.

\section{Discussion}

The digitization of the public sector should not be considered solely a technical project or a project merely about improving efficiency, freeing up resources and modernizing service delivery. Instead, digitization should be seen as a substantial reform driven by strong programmatic ideas and ideals and an often-unquestioned digitization imperative. Our discussion above has shown that the organization studies literature treats certain aspects of digitization in the public sector without explicitly discussing or problematizing how public sector organizations are different from other kinds of organizations and how these specific conditions affect change caused by digitization. In organization studies of digital technology, the themes of formal bureaucratic structures, accountability and professions are, in fact, touched upon, but they are not theorized as particular aspects of the public sector and the digitization agenda. We propose that while the three aspects can be treated as separate analytical 
categories, they overlap in practice and in empirical studies because they are connected in practice and by a specific ethos of office, which is historically tied to the public sector and its professionals (Weber, 1978). According to du Gay (2008, p. 338), this ethos is "a historically contingent and variable 'life order' constituting a distinctive ethical milieu in its own right, one whose practices of formalistic impersonality gave rise to certain substantive ethical goals". This ethos is characterized by a commitment to the execution of the administration's purpose, which is redefined by digitization reforms.

Formal bureaucratic structures, accountability and professionals are embedded in this particular ethos. The formal bureaucratic structures mirror certain values, such as merit, hierarchy, and expertise. The more horizontal structures and relations afforded by digital technologies challenge the traditional ethos of office in the public sector. This ethos also appears to be challenged by a shift in accountability, which seems to become more externalized and reformulated due to an increasing demand for new forms of standardized documentation. Finally, if we assume that professionals among public servants are tied to a particular ethos that is intrinsically linked to certain practices, then professionals cannot be left untouched by changes in these practices.

\section{A research agenda}

On this basis, we propose a research agenda on the transformation of work in digitized public sector organizations. With this research agenda, we offer a distinctly organizational approach to digitization in the public sector because organization studies provide a vocabulary where work is at the center and organizational key aspects such as formal bureaucratic structure, accountabilities and professions make it possible to ask new and potentially productive questions to digitization. This agenda can fruitfully draw on and contribute specifically to the research strand in organization studies, which draws inspiration from science and technology studies (STS). This stream of literature studies and theorizes how work, organization and technologies, including digital technologies, mutually constitute each other (Kallinikos, 2006; Orlikowski, 2007; Petrakaki, et al., 2016; Wajcman, 2015; Zammuto et al., 2007; Zuboff, 1988). An STS-inspired vocabulary is useful because it emphasizes that the implementation of digital technologies does not necessarily lead to specific outcomes. Instead outcomes depend on the organizational context, users 
and technologies. It also directs attention to situated practices and encourages detailed empirical studies of work at the everyday level. Our analysis suggests that such an approach may address the gap in the current literature on public sector organizations and digitization.

An STS approach provides a particular understanding of key terms in the proposed research agenda, such as digitization, technology, work, and transformation of work. It implies that digitization is not merely a technical issue and we propose that the definition of digitization is expanded - as argued in our introduction - and further theorized. First, it can be understood as a reform program that pursues the twinned precepts of economic efficiency and good practice (Strathern, 2000), which are pushed by such institutions as the EU, OECD, and national governments. Second, digitization can be understood as the practical implementation of diverse digital technologies and work procedures, even though the results of such implementations may not fulfill the expectations formulated in digitization strategies. This dual definition of digitization makes it possible to grasp the simultaneously diverse and crosscutting character of values and practices connected to public sector digitization (ibid.). Also building on STS insights, our understanding of technology in organizational contexts is that technology, work and organization mutually shape each other (Grint and Woolgar, 1997). This interplay has to be taken into consideration when analyzing how digitization changes public sector organizations at the level of everyday work. Technology is not a stable, predictable entity. It is shaped by social forces (e.g., the digitization agenda), technical design (e.g., specific online platforms), and local users (e.g., public sector managers and employees) who are, in turn, shaped by the technology. Work can be defined as the concrete activities that people perform and are engaged in when they are employed in organizations (Barley and Kunda, 2001). Therefore, studying the transformation of work is not a question of assessing the difference from 'before digitization' to the present, but one of investigating how public sector employees deal with the current digitization imperative in their work practices.

These definitions are in line with the state-of-the-art literature on technology, work and organization, which is oriented towards grasping the specificities of technology use in particular contexts. As digitization of the public sector happens simultaneously across very large institutions, rather than in individual companies, it is relevant to 
study the transformation of work across the entire sector and pose ambitious questions about the organizational consequences of its digitization.

\section{Conclusion and implications for change management} The purpose of this article was to create a basis for understanding how digitization changes work in public sector organizations. We established that digitization is a substantial reform aimed at restructuring the public sector and we argued that this phenomenon is still primarily investigated as an implementation issue in single organizations or theorized as a reform issue on a macro level. Based on the assumption that organization studies can contribute to our understanding of the transformation of work, the article examined what we can learn from organization studies of digital technologies and changes in public organizations. Our analysis of the organizational studies literature has identified various examples of how digital technologies change important aspects of public sector organizations relating to formal bureaucratic structures, accountability and professionals. The analysis allows us to conclude that no systematic account exists in organization studies of changes due to digitization specific to the public sector. On that basis, we have proposed a research agenda that allows us to produce systematic knowledge about how work practices in the public sector change with digitization. The research agenda draws on organization theory and Science and Technology Studies because these perspectives allow for situated investigations of the interplay between technology, organization and work. It encourages us to investigate how managers redesign structures, create new tasks, new occupational categories, new groups, and new routines. It leads our attention to how managers and employees handle new demands to registration, information management, delegation of work to technology and delegation of responsibility. And it pushes us to inquire into how employees redefine professional relations and identities in interplay with new tasks and positions in the organization.

The knowledge produced by current and future research in this area is directly applicable for change management. To react productively on the digitization imperative, public managers need to deepen their knowledge of the organizational dimension of digitization. They can no longer think in terms of information technology and IT departments, but must cultivate a broader approach. For instance, if digitization of public sector organizations is not just a matter of implementing a range 
of technologies, but about integrating organizational strategies and digital technologies, managers need more knowledge about the development of appropriate new organizational forms, such as agile organizations or project organizations. Also, managers need knowledge sharing about how digitization can be approached. There is an overlooked potential in sharing experiences across the sector, since public sector organizations are at the same time recipients of the same demands and a diverse aggregation of institutions. Finally, managers of public organizations need more knowledge about implementing digitization reforms in relation to other reforms. Digitization must be seen in relation to a constant reform pressure in various political areas, because these reforms also entail changes that have implications for digitization projects. It falls outside the scope of this article to develop more specific recommendations, but we think that future research, inspired by our proposed research agenda on public sector digitization, could inform public administration managers and help them qualify organizational change initiatives in a public sector context. 


\section{References}

Abbott, A. (1988). The system of professions: An essay on the division of expert labor. Chicago: University of Chicago Press.

Arellano-Gault, D., Demortain, D., Rouillard, C. and Thoenig, J. (2013). Bringing

Public Organization and Organizing Back In. Organization Studies, 34(2), 145-167.

Barley, S. and Kunda, G. (2001). Bringing work back in. Organization Science 12(1), 76-95.

Barrett, M., Oborn, E., Orlikowski, W. and Yates, J. (2012). Reconfiguring boundary relations: Robotic innovations in pharmacy work. Organization Science 23(5), 1448-1466.

Bejerot E. and Hasselbladh H. (2013). Forms of intervention in public sector organizations: Generic traits in public sector reforms. Organization Studies, 34(9), 1357-1380.

Bekkers, V. and Homburg, V. (2005). E-government as an information ecology: Backgrounds and concepts. IOS Press.

Bloomfield, B. and McLean, C. (2003). Beyond the walls of the asylum: information and organization in the provision of community mental health services. Information and Organization 13(1), 53-84.

Boisot, M. (2006). Moving to the edge of chaos: bureaucracy, IT and the challenge of complexity. Journal of Information Technology 29(4), 239-248.

Boudreau, M-C., Serrano, C. and Larson, K. (2014). IT-driven identity work: Creating a group identity in a digital environment. Information and Organization, 24(1), $1-24$.

Buffat, A. (2015). Street-level bureaucracy and E-government. Public Management Review, 17(1), 149-161. 
Constantinedes, P. and Barrett, M. (2006). Negotiating ICT development and use: The case of a telemedicine system in the healthcare region of Crete. Information and Organization. 16(1), 27-55.

Du Gay, P. (2000). In praise of bureaucracy: Weber-organization-ethics. Sage.

Du Gay, P. (2008). Without affection or Enthusiasm. Problems of Involvement and Attachment in 'Responsive' Public Management. Organization 15(3), 335-353.

Du Gay, P. (2009). In defence of mandarins: Recovering the 'core business' of public management. Management \& Organizational History, 4(4), 359-384.

Du Gay, P. and Vikkelsø, S. (2017). For Formal Organization. The Past in the Present and Future of Organization Theory. Oxford, Oxford University Press.

Davis, C. and Hufnagel, E. (2007). Through the eyes of experts: A socio-cognitive perspective on the automation of fingerprint work. Mis Quarterly, 31(4), 681703.

Dunleavy, P., Margetts, H., Bastow, S. and Tinkler, J. (2006). New public management is dead-long live digital-era governance. Journal of Public Administration Research and Theory, 16(3), 467-494.

Ejersbo, N. and Greve, C. (2017). Digital Era Governance Reform and Accountability: The Case of Denmark. Christensen, T. and Lægreid, P. (Eds). The Routledge Handbook to Accountability and Welfare State Reforms in Europe, Routledge, 267-279.

Ford, M. (2015). The Rise of the Robots. Technology and the Threat of Mass Unemployment. Oneworld Publications.

Galbraith, J. R. (1977). Organization design. Addison-Wesley Pub. Co.

Grint, K. and Woolgar, S. (1997). The Machine at Work: Technology, Work and Organization, Cambridge, Polity Press 
Hardy, C. A. and Williams, S. P. (2011). Assembling e-government research designs: A transdisciplinary view and interactive approach. Public Administration Review, 71(3), 405-413.

Harris, M. (2006). Technology, innovation and post - bureaucracy: the case of the British Library. Journal of Organizational Change Management, 19(1), 80-92.

Harris, M. (2008). Digital Technology and Government in Transition. The case of the British Library. Human Relations 61(5), 741-758.

Hossan, C., Dixon, C., and Brown, D. (2013). Impact of group dynamics on eservice implementation. A qualitative analysis of Australian public sector organisational change. Journal of Organizational Change Management, 26(5), 853-873.

Hung, S., Chen, C. C. and Lee, W. (2009). Moving hospitals toward e-learning adoption: an empirical investigation. Journal of Organizational Change Management, 22(3), 239-256.

Hussenot, A. (2008). Between structuration and translation: an approach of ICT appropriation. Journal of Organizational Change Management, 21(3), 335-347.

Introna, L., Hayes, N. and Petrakaki, D. (2009). The working out of modernization in the public sector: The case of an e-government initiative in Greece. International Journal of Public Administration, 33(1), 11-25.

Jæger, B. and Löfgren, K. (2010). The history of the future: Changes in Danish egovernment strategies 1994-2010. Information Polity, 15(4), 253-269.

Kallinikos, J. (2006). The Consequences of Information: Institutional Implications of Technological Change. Edward Elgar.

Kraemer, K. L. and King, J. L. (1986). Computing and public organizations. Public Administration Review, 46, 488-496. 
Landsbergen Jr, D. and Wolken Jr, G. (2001). Realizing the promise: Government information systems and the fourth generation of information technology. Public administration review, 61(2), 206-220.

Lanzara, G. F. (2010). Reshaping Practice Across Media: Material Mediation, Medium Specificity and Practical Knowledge in Judicial Work. Organization Studies, 30(12), 1369-1390.

Lips, M. (2012). E-government is dead: Long live public administration 2.0. Information Polity, 17(3, 4), 239-250.

Lipsky, M. (2010). Street-level bureaucracy, 30th ann. ed.: Dilemmas of the individual in public service. Russell Sage Foundation.

Maciejewski, M. (2017). To do more, better, faster and more cheaply: using big data in public administration. International Review of Administrative Sciences, 83(1), $120-135$.

Margetts, H. (2009). Public management change and e-government: The emergence of digital-era governance. Routledge Handbook of Internet Politics, 114-127.

OECD 2009. Rethinking e-Government Services. User-centred Approaches. OECD.

Orlikowski, W.J. (2007). Sociomaterial Practices: Exploring Technology at Work. Organization Studies, 28(9), 1435-1448.

Perrow, C. (1967). A Framework for the Comparative Analysis of Organizations. American Sociological Review, 32(2), 194-208.

Petrakaki, D., Klecun, E. and Cornford, T. (2016). Changes in healthcare professional work afforded by technology: The introduction of a national electronic patient record in an English hospital. Organization, 23(2), 206-226.

Pick, D., Teo, S. T. T., Tummers, L. and Newton, C. (2015). Advancing knowledge on organizational change and public sector work. Journal of Organizational Change Management, 28(4). 
Pors, A. S. (2015). Becoming digital - passages to service in the digitized bureaucracy. Journal of Organizational Ethnography, 4(2), 177-192.

Power, M. (1999). The Audit Society. Second edition. Oxford University Press.

Segrest, S. L., Domke-Damonte, D. J., Miles, A. K. and Anthony, W. P. (1998). Following the crowd: social influence and technology usage. Journal of Organizational Change Management, 11(5), 425-445.

Strathern, M. (2000). Audit cultures: Anthropological studies in accountability, ethics, and the academy. Psychology Press.

Susskind, R. and Susskind, D. (2015). The Future of the Professions. How Technology will Transform the Work of Human Experts. Oxford University Press.

Sørensen, C. and Pica, D. (2005). Tales from the police: Rhythms of Interaction with Mobile Technologies. Information and Organization 15(2), 125-149.

Taylor, F. (1911). The Principles of Scientific Management. New York: Dover Publications.

Tolsby, J. (2000). Taylorism given a helping hand. Journal of Organizational Change Management, 13(5), 482-492.

Toren, N. (1975). Deprofessionalization and its sources A preliminary analysis. Work and Occupations, 2(4), 323-337.

Wajcman, J. (2015). Pressed for Time. The Acceleration of Life in Digital Capitalism. The University of Chicago Press.

Wajcman, J. (2017). Automation: is it really different this time? The British Journal of Sociology, 68(1), 119-127.

Watts, S. (2016). The Internet of Things (IoT): Applications, technology, and privacy issues. Nova Science Publisher. 
Weber, M. (1978). Economy and Society (2 Vols). Los Angeles, CA, University of California Press.

Woodward, J. (1958). Management and technology. London: Her Majesty's Stationary Office.

Yeo, R.K. and Marquardt, M.J. (2015). “Think before you act” organizing structures of action in technology-induced change' Journal of Organizational Change Management. 28(4), 511-528.

Zammuto, R.F, Griffith, T.L, Majchrzak, A. and Faraj, S. (2007). Information Technology and the Changing Fabric of Organization. Organization Science 18(5), 749-762.

Zuboff, S. (1988). In the age of the smart machine: The future of work and power. Basic Books. 